\title{
MENINGKATKAN MOTIVASI GURU MENCIPTAKAN MEDIA PEMBELAJARAN MELALUI TEKNIK PENDAMPINGAN DI TK TUNAS HARAPAN KOTA TIMUR
}

\author{
Salma Alhasni \\ TK Tunas Harapan Kota Timur \\ salma@gmail.com
}

Received: 26 November 2019; Revised: 4 Desember 2019; Accepted: 24 Desember 2019

\begin{abstract}
ABSTRAK
Masalah dalam penelitian tindakan kelas ini adalah Apakah dengan penerapan Teknik Pendampingan dapat meningkatkan motivasi guru menciptakan media pembelajaran di TK Tunas Harapan Kota Gorontalo?. Adapun tujuan penelitian ini adalah untuk meningkatan motivasi guru menciptakan media pembelajaran melalui penerapan Teknik Pendampingan di TK Tunas Harapan. Penelitian ini merupakan penelitian tindakan sekolah dengan metode analisis deskriptif yang meliputi siklus I dan siklus II, dengan langkah perencanaan, tindakan, observasi, dan refleksi. Hasil siklus I menunjukan dari 2 orang guru yang dilatih melalui proses pendampingan, diperoleh bahwa 1 orang atau 50\% memiliki motivasi menciptakan media pembelajaran kemudian mengalami peningkatan pada siklus II yaitu dari 2 orang guru, diperoleh bahwa $100 \%$ telah memiliki motivasi menciptakan media pembelajaran bagi siswa TK. Dengan demikian indikator kinerja dikatakan berhasil. Simpulan dari penelitian ini adalah Teknik Pendampingan dapat meningkatkan motivasi guru menciptakan media pembelajaran di TK Tunas Harapan
\end{abstract}

Kata Kunci: Teknik Pendampingan dan Motivasi Guru

\section{PENDAHULUAN}

Konsep pendidikan anak usia dini di Indonesia mencakup pendidikan anak dari mulai usia nol tahun sampai enam tahun. Jadi mungkin lebih tepat dikatakan pendidikan sebelum masa kanak-kanak. Sebelum usia dua tahun namanya bukan anak tetapi inform. Di Amerika Serikat anak usia dini (early child school education) sampai usia tujuh atau delapan tahun atau sampai kelas tiga sekolah dasar (SD). Sebelum usia empat tahun bukan termasuk pendidikan, tetapi kelompok bermain (child chair). Anak-anak diberi kesempatan bermain di kelas secara bebas, sehingga mereka merasa senang di kelas. Tujuannya adalah untuk merangsang pertumbuhan sel saraf di otak (neurosikologi). Neurosikologi adalah teori psikologi yang menjelaskan tentang pertumbuhan sel saraf otak. Mencermati hal tersebut, maka seorang guru TK seyogyanya harus memiliki motivasi untuk menciptakan media pembelajaran yang menarik dan bermakna sehingga bisa menggairahkan situasi belajar siswa TK yang pada umumnya masih dalam taraf menyukai permainan. Oleh karena itu,berdasarkan fakta pada kegiatan observasi awal yang peneliti lakukan di TK Tunas Harapan menunjukan bahwa motivasi guru dalam membuat media masih rendah. Masih ditemukan $100 \%$ atau sekitar 2 orang guru yang mengajar di sekolah tersebut belum memiliki motivasi menciptakan media pembelajaran. Mereka hanya mengharapkan media yang sudah ada (turun-temurun) ataupun media yang bersumber dari bantuan Pemerintah sehingga siswa TK cenderung 
bosan karena tidak ada perubahan media pembelajaran. Mencermati hal tersebut, maka perlu adanya strategi praktis dan efisien untuk mengatasi permasalahan tersebut yaitu melalui Teknik Pendampingan sebagaimana yang dikatakan oleh Rokhmah (2012:4) yaitu bahwa pendamping adalah perorangan atau lembaga yang melakukan pendampingan, dimana antara kedua belah pihak (pendamping dan yang didampingi) terjadi kesetaraan, kemitraan, kerjasama, dan kebersamaan tanpa ada batas golongan (kelas atau status sosial) yang tajam. Berdasarkan hal tersebut, maka peneliti akan mengkajinya lebih detail secara ilmiah melalui penelitian tindakan sekolah yang diformulasikan dalam judul "Meningkatkan motivasi guru menciptakan media pembelajaran melalui teknik pendampingan di TK Tunas Harapan Kota Timur"

\section{TINJAUAN PUSTAKA}

\section{Hakikat Motivasi Guru}

Istilah motivasi memiliki pengertian yang beragam baik yang berhubungan dengan perilaku individu maupun perilaku organisasi. Menurut Sumantri (dalam Karweti, 2010:78), motivasi biasanya digunakan untuk menunjukkan suatu pengertian yangmelibatkan tiga komponen utama, yaitu (1) pemberi daya pada perilaku manusia (energizing), (2) pemberi arah pada perilaku manusia (directing), (3) bagaimana perilaku itu dipertahankan(sustaining). Hal ini tentunya berlaku untuk dunia pendidikan dengan lingkup organisasi yakni lembaga pendidikan sekolah dasar. Guru sebagai motor penggerak lembaga pendidikan sekolah dasar diharapkan memiliki motivasi kerja guru yang menyebabkan dirinya bersemangat dalam mengajar. Oleh karena itu, Guru bekerja karena adanya kebutuhan yang harus dipenuhi menurut Kenneth (dalam Uno, 2011:68) yakni; (1) kebutuhan hidup, (2) kebutuhan keamanan, (3) kebutuhan berafiliasi, (4) kebutuhan akan adanya penghargaan, (5) kebutuhan untuk tidak bergantung pada orang lain, (6) kebutuhan akan prestasi dan kompetensi. Supartini, (2001:1) mengemukakan bahwa apabila para guru mempunyai motivasi kerja yang tinggi, mereka akan terdorong dan berusaha untuk meningkatkan kemampuannya merencanakan,melaksanakan, dan mengevaluasi kurikulum yang berlaku di sekolah sehingga diperoleh hasil kerja yang maksimal. Motivasi kerja merupakan salah satu faktor yang ikut menentukan tinggi rendahnya kinerja seorang guru. Motivasi juga berhubungan dengan faktor-faktor psikologis seseorang sebagai wujud hubungan antara sikap, kebutuhan dan kepuasan yang terjadi dalam diri manusia.

Rangsangan bagi manusia adalah berusaha memenuhi kebutuhannya baik yang bersifat material maupun non material. Pemenuhan kebutuhan yang bersifat material merupakan motivasi kerja yang berasal dari luar individu guru namun besar pengaruhnya kepada kondisi kepuasan psikologis seorang guru. Terpenuhinya kebutuhan guru, minimal kebutuhan pokoknya, guru akan lebih fokus dalam bekerja dan menunjukkan kinerja yang sesuai dengan tuntutan profesinya.

\section{Hakikat Pendidikan Anak Usia Dini}

Pendidikan anak usia dini menurut Undang-Undang Sistem Pendidikan Nasional (UU Sisdiknas) Nomor 20 tahun 2003, adalah suatu upaya pembinaan yang ditujukan kepada anak sejak lahir sampai dengan usia 6 tahun yang dilakukan melalui pemberian rangsangan pendidikan untuk membantu pertumbuhan dan perkembangan jasmani dan rokhani agar anak memiliki kesiapan dalam memasuki pendidikan lebih lanjut. 
Pendidikan anak usia dini dianggap penting karena ketika anak lahir telah dibekali oleh Tuhan dengan berbagai potensi genetis, tetapi lingkungan memberi peran sangat besar dalam pembentukan sikap kepribadian dan pengembangan kemampuan anak. Selain itu jaringan otak manusia yang paling menentukan terjadi ketika anak masih berusia dini, dan usia 4 tahun pertama merupakan usia yang paling rawan. Yang perlu diperhatikan dari anak adalah seberapa jauh anak merasa diperhatikan, diberi kebebasan atau kesempatan untuk mengekspresikan ide-idenya, dihargai hasil karya atau prestasinya, didengar isi hatinya, tidak ada paksaan atau tekanan, ancaman terhadap dirinya dan mendapatkan layanan pendidikan sesuai tingkat usia dan perkembangan kejiwaannya. Anak-anak yang tumbuh dalam tekanan-tekanan, misalnya rasa takut, khawatir, stress, dan sebagainya ketika remajanya akan merasakan suatu dorongan-dorongan agresif atau nakal yang menimbulkan efek negatif. Mungkin anak itu kreatif tetapi kreatifitasnya menuju ke arah yang negatif bahkan bisa ke arah sadis. Tetapi jika anak-anak diperhatikan (care) bahkan sejak masa bayi hingga muncul rasa semangat, maka petumbuhannya akan sangat teratur sekali sehingga dia berpikir logis, lebih memperhatikan (care) kepada orang lain. Ibu memiliki peran sangat besar terhadap pendidikan anak-anak mulai sejak bayi. Ketika beranjak lebih besar lebih bagus jika anak itu dikirimkan ke child care atau kelompok bermain. Meskipun untuk saat sekarang yang mampu menitipkan anaknya ke tempat bermain adalah orang-orang yang kelas ekonominya menengah ke atas, karena kelompok menengah ke bawah jarang yang menitipkan anaknya di kelompok bermain. Namun demikian yang diperlukan dari seorang ibu adalah tahu cara mengasuh anak karena itu bagian dari tujuan pendidikan, sehingga anak-anak akan tumbuh bukan hanya secara fisik saja tetapi juga secara logis bagus pula tumbuh berkembang secara psikologisnya dan secara neurosis pada track yang bagus.

\section{Hakikat Media Pembelajaran}

Gerlach\&Ely (dalam Arsyad, 2011:3) dalam sebuah mengatakan bahwa media apabila dipahami secara garis besar adalah manusia, materi atau kejadian yang membangun kondisi yang membuat siswa mampu memperoleh pengetahuan, keterampilan, atau sikap. Association of Education and Comunication Technology (AECT) member batasan tentang media sebagai segala bentuk dan saluran yang digunakan untuk menyampaikan pesan dan informasi. Sardiman (2007:21) mengatakan bahwa media adalah segala sesuatu yang dapat dipergunakan untuk menyalurkan pesan dari pengirim ke penerima pesan sehingga dapat merangsang pikiran, perasaan, perhatian dan minat serta pengetahuan siswa bertambah lebih banyak sehingga proses mengajar terjadi. Daryanto (2010:5) kata media berasal dari bahasa latin adalah bentuk jamak dari medium yaitu sebagai alat dan bahan kegiatan pembelajaran. Dari berbagai batasan di atas dapat dirumuskan bahwa media adalah segala sesuatu yang dapat dipergunakan untuk meyalurkan pesan dan dapat merangsang pikiran, dapat membangkitkan semangat, perhatian, dan kemauan siswa sehingga dapat mendorong terjadinya proses pembelajaran pada diri siswa. Selanjutnya, Allen (dalam Daryanto, 2010:18) mengatakan terdapat Sembilan kelompok media yaitu, audio-visual, film, televisi, objek tiga dimensi, rekaman, pelajaran terprogram, demonstrasi, buku teks cetak, dan sajian lisan. 


\section{Manfaat Media Pembelajaran}

Media merupakan salah satu komponen yang sangat penting dalam proses belajar mengajar. Apabila media pengajaran dapat dimanfaatkan secara baik dan tepat, akan mampu memberikan beberapa fungsi yang berguna bagi pengelola pengajaran karena selain dapat menarik perhatian dan minat belajar siswa, juga dapat berfungsi sebagai alat bantu untuk mempermudah bagi guru dalam menyajikan materi, maupun bagi siswa dalam memahami materi yang disajikan. Kemp \& Dayton (dalam Abimanyu 2011:21) mengemukakan beberapa manfaat media dalam pembelajaran yaitu:

a) Penyampaian pelajaran menjadi lebih baku. Setiap pelajar yang melihat atau mendengar penyajian melalui media menerima pesan yang sama. Meskipun para guru menafsirkan isi pelajaran dengan cara yang berbeda-beda, dengan penggunaan media ragam hasil tafsiran itu dapat dikurangi sehingga informasi yang sama dapat disampaikan kepada siswa sebagai landasan untuk pengkajian, latihan, dan aplikasi lebih lanjut.

b) Pembelajaran bias lebih menarik. Media dapat diasosiasikan sebagai penarik perhatian dan membuat siswa tetap terjaga dan memperhatikan.

c) Pembelajaran menjadi lebih interaktif dengan diterapkannya teori belajar dan prinsip-prinsip psikologis yang diterima dalam hal partsipasi siswa, umpan balik, dan penguatan.

d) Lama waktu pembelajaran yang diperlukan dapat dipersingkat karena kebanyakan media hanya memerlukan waktu singkat untuk mengantarkan pesan-pesan dan isi pelajaran dalam jumlah cukup banyak dan kemungkinannya dapat diserap oleh siswa.

e) Kualitas hasil belajar dapat ditingkatkan bilamana integrasi kata dan gambar sebagai media pembelajaran dapat mengkomunikasikan elemen-elemen pengetahuan dengan cara yang terorganisasikan dengan baik, spesifik, dan jelas.

f) Pembelajaran dapat diberikan kapan dan dimana diinginkan atau diperlukan terutama jika media pembelajaran dirancang untuk penggunaan secara individu.

g) Sikap positif siswa terhadap apa yamg mereka pelajari dan terhadap proses belajar dapat ditingkatkan.

h) Peran guru dapat berubah kearah yang lebih positif, beban guru untuk penjelasan berulang-ulang mengenai isi pelajaran dapat dikurangi bahkan dihilangkan.

\section{Penerapan Teknik Pendampingan}

Pelatihan merupakan kegiatan yang sering dilakukan di berbagai lembaga dalam meningkatkan kemampuan tenaga/karyawan untuk pencapaian tujuan lembaga tersebut. Terkait dengan hal tersebut, Simamora (1997) "Pelatihan adalah proses sistematik pengubahan perilaku para karyawan dalam suatu arah guna meningkatkan tujuan-tujuan organisasional." Menurut Armstrong (1991) "Training is A planned process to modify attitude, knowledge or skill behavior through learning experience to achieve effective peformance in an activity or of activities'. (Badu, 2012:31). Kenneth Robinson (1981), dalam Sudirman (2001:20) mengemukakan bahwa:"Training, Therefore we are seeking by any instructional or experiential means to develop a person behaviour patterns in the areas of knowledge, skill or attitude in order to achievea disered, standar". Dengan demikian pelatihan merupakan instruksional atau experensial untuk mengembangkan pola-pola perilaku seseorang dalam bidang pengetahuan keterampilan atau sikap untuk 
mencapai standar yang diharapkan.Gardner (1981), dalam Sudirman (2001:21) menjelaskan bahwa "Training can be defined broadly is the techniques and arrangement aimed at fostering and experiencing learning. The focus in on learning".Gardner mengemukakan, bahwa pelatihan itu lebih difokuskan pada kegiatan pembelajaran. Pendapat ini didukung oleh Kamil (2010: 151-152) mendefinisikan pelatihan sebagai proses pemberdayaan dan pembelajaran, artinya individu (anggota masyarakat) harus mempelajari sesuatu (materi) guna meningkatkan kemampuan, keterampilan dan tingkah laku dalam pekerjaan dan kehidupan seharai-hari dalam menopang ekonominya (pendapatan).Dengan demikian, kegiatan pelatihan lebih ditekankan pada peningkatan pengetahuan, keahlian/ keterampilan (skill), pengalaman, dan sikap peserta pelatihan tentang bagaimana melaksanakan aktivitas atau pekerjaan tertentu.

\section{Peran dan fungsi kegiatan Pendampingan}

Kegiatan pendampingan memiliki peran dan fungsinya. Adapun peran kegiatan pendampingan menurut Suharto (2005:95) adalah peran pendampingan berpusat pada empat bidang tugas yaitu; (1) Fasilitator Pendamping berperan sebagai pemberi motivasi dan kesempatan bagi masyarakat. Pendamping bertugas melakkan mediasi, negoisasi dan menjadi model (2) Penguatan (empowering) Seorang pendamping bertugas untum memperkuat kapasitas masyarakat dalam bidang pendidikan dan pelatihan.Pemandu berperan dalam memberikan pendapat yang berguna untuk memperluas pengetahuan dan pengalaman masyarakat yang didampinginya. (3) Perlindungan (protecting) Peran dari pendamping dalam hal perlindungan dalah dengan melakukan pembelaaan, menggunakan media, meningkatkan hubungan antar masyarakat. (4) Pendukung (supporting) Peran pendamping dalam hal ini adalah mendukung terjadinya peruahan yang lebih baik pada masyarakat. Pendamping dituntut mampu mengembangkan ketampilan dasar yang dimilikinya seperti menjalin hubungan dengan masyarakat, mengelola kelompok masyarakat dan berkomunikasi.Pendapat ini didukung oleh HAPMI (Purossani, 2015:40-41) yang menyatakan bahwa Peran kegiatan pendampingan menenmpatkan seorang pendamping sebagai; (1) Sebagai Pembimbing Pendamping disini bertugas untuk memberikan bimbingan atau pembinaan kepada warga belajar.Dan juga memberikan banyak informas ataupun pengetahuan sehingga mereka dapat menyelesaikan masalah yang dihadapi. (2) Sebagai enabler Pendamping harus mampu memberi motivasi kepada masyarakat dan memberikan pemahaman tentang cara menganalisa masalah yang timbul. Sehingga mereka mampu menyelesaikan masalah tersebut dengan mandiri.(3) Sebagai Ahli Pendamping harus memiliki ketramnpilan yang khusus dengan memberikan penjelasan yang nyata dalam kehidupan sehari-hari untuk mendorong masyarakat maupun warga belajar agar dapat memilih mana yang harus diberikan tindakan sesuai masalah yang dihadapinya.

\section{METODE PENELITIAN}

Penelitian ini dilaksanakan di TK Tunas Harapan Kota Gorontalo selama3 bulan yaitu Agustus-Oktober 2017. Penelitian ini diawali dengan observasi awal yang selanjutnya menjadi landasan untuk melaksanakan tindakan siklus 1 dan 2 . ini dilaksanakan di TK Tunas Harapan Kota Gorontalo dengan jumlah guru sebagai subyek adalah 2 orang dengan karakteristik yang berbeda 
Tasjid (2014:67) menjelaskan bahwa Setiap siklus atau prosedur langkahlangkah yang akan dilakukan dalam penelitian ini dilaksanakan terdiri dari empat komponen kegiatan pokok, yaitu (a) perencanaan (planning), (b) pelaksanaan tindakan (action) (c) refleksi (reflection), yang pada pelaksanaannya keempat komponen pokok itu berlangsung secara terus menerus dengan diselipkan modifikasi pada komponen perencanaan berupa perbaikan perencanaan dan tidakan.

Secara skematis prosedur Penelitian Tindakan Sekolah (PTS) disajikan pada gambarberikut:

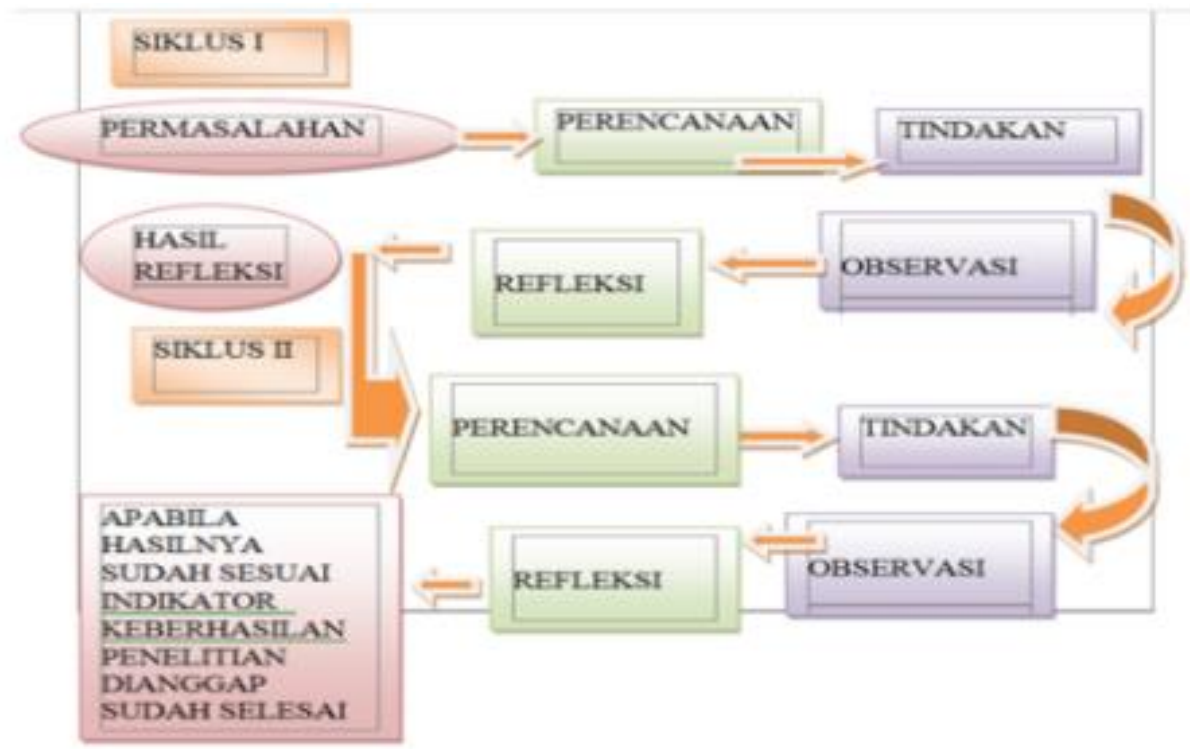

Gambar 1 Skema Penelitian Tindakan Sekolah

Untuk mengumpulkan data dalam penelıtıan inı maka penelıtı menggunakan beberapa teknik pengumpulan data sebagai berikut; (1) Observasi dan (2) Wawancara.

\section{Teknik Analisis Data}

Analisa data yang peneliti gunakan adalah analisis diskriptif komparatif menghitung peningkatannyaminimal 10\% dengan membandingkan kondisi awal, hasil siklus I dan hasil siklus II. Analisa nilai yang digunakan sebagai berikut:

1) Baik Sekali $=91-100$

2) Baik $=76-90$

3) Cukup $=61-75$

4) Kurang $=51-60$

5) Kurang Sekali $=<50$

\section{HASIL PENELITIAN DAN PEMBAHASAN}

\section{Observasi awal}

Adapun hasil observasi awal menunjukan bahwa 100\% guru di TK Tunas Harapan belum memiliki motivasi menciptakan media pembelajaran terbaru.

\section{Siklus I}

Sebelum masuk pada hasil tindakan siklus 1, berikut ditampilkan data guru di TK Tunas Harapan berdasarkan pembagian tugas mengajar tahun pelajaran 2017/2018. 
Tabel 4.1 Data Guru TK Tunas Harapan T.P 2017-2018

\begin{tabular}{lllll}
\hline No & Nama Guru & Status & Jabatan & Ket \\
\hline 1 & Salma Alhasni, S.Pd & PNS & Kepala Sekolah & \\
2 & Norma Ibrahim,S.Pd & Non PNS & Guru Kelompok A & \\
3 & Saida Ahmad,S.Pd & Non PNS & Guru Kelompok B & \\
\hline
\end{tabular}

Sumber Data: TK Tunas Harapan, 2017

Adapun hasil tindakan pada siklus I dapat dilihat pada tabel 4.1 di bawah ini.

Tabel 4.2 Hasil Tindakan Siklus 1

\begin{tabular}{lllll}
\hline No & Jumlah Guru (Orang) & Nilai & Prosentasi (\%) & Kategori \\
\hline 1 & 1 & 80 & 50 & Baik \\
2 & 1 & 65 & 50 & Cukup \\
Total & $\mathbf{2}$ & $\mathbf{1 4 5}$ & $\mathbf{1 0 0 , 0}$ & \\
\hline
\end{tabular}

Berdasarkan tabel tersebut, dapat dijelaskan bahwa:

1) Dari 2 orang guru yang dinilai, diperoleh bahwa terdapat 1 orang atau $50 \%$ telah mengalami peningkatan motivasi menciptakan media pembelajaran

2) Dari 2 orang guru,terdapat 1 orang atau 50\% yang belum memiliki motivasi menciptakan media pembelajaran

\section{Refleksi}

Kegiatan ini dilaksanakan pada akhir siklus dengan tujuan untuk mengetahui hasil yang telah diperoleh dan untuk mendapatkan gambaran apakah tindakan yang telah dilakukan telah mempengaruhi motivasi guru Berdasarkan kelemahan-kelemahan yang terjadi pada siklus I, dan melihat motivasi guru masih rendah, atau belum mencukupi standar indikator kinerja, maka peneliti bekerjasama dengan guru sebagai mitra mengadakan kegiatan refleksi pada siklus I.Sesuai dengan hasil refleksi, ditemukan beberapa kelemahan pada pelaksanaan kegiatan adalah: (a) pelaksanaan pendampingan yang ada belum efektif; (b) Langkah-langkah pendampingan belum efektif dan efisien;(c) masih terdapat beberapa orang guru yang belum memiliki motivasi menciptakan media pembelajaran;(d) Administrasi pembelajaran terkesan hanya ikut-ikutan asal jadi saja; (e) kurangnya motivasi dan controlling.

\section{Deskripsi Siklus II}

Hasil yang diperoleh dapat dilihat pada tabel 4.3 berikut ini

Tabel 4.3 Hasil Tindakan Siklus 2

\begin{tabular}{lllll}
\hline No & Jumlah Guru (Orang) & Nilai & Prosentase (\%) & Kategori \\
\hline 1 & 1 & 98 & 50 & Baik Sekali \\
2 & 1 & 90 & 50 & Baik \\
Total & $\mathbf{2}$ & $\mathbf{1 8 8}$ & $\mathbf{1 0 0}$ & \\
\hline
\end{tabular}

Berdasarkan tabel tersebut, dapat dijelaskan bahwa:

a. Dari 2 orang guru, diperoleh bahwa seluruhnya atau100\% telah memiliki motivasi menciptakan media pembelajaran yang sangat baik

b. Daya serap mencapai $94 \%$

\section{Pembahasan}

Berdasarkan hasil penelitian, jelaslah bahwa Teknik Pendampingansangat baik digunakan untuk meningkatkan Motivasi Guru menciptakan media pembelajaran di TK Tunas Harapan. Dari hasil perbaikan langkah-langkah tersebut, nampak ada perubahan 
dari siklus sebelumnya yaitu pada siklus 2 terdapat 2 orang atau 100\% telah memiliki Motivasi menciptakan media pembelajaran yang sangat baik. Berdasarkan gambaran di atas, sangatlah jelas Motivasi Guru menciptakan media pembelajaran meningkat pada siklus I sampai dengan pelaksanaan tindakan Siklus 2, dengan demikian terbukti setelah melalui penelitian tindakan sekolah ini, Motivasi Guru menciptakan media pembelajaran akan meningkat melalui Teknik Pendampingan. Dengan demikian hipotesis tindakan dalam penelitian ini dapat Diterima.

\section{KESIMPULAN}

Berdasarkan pembahasan pada bab sebelumnya, maka dapat disimpulkan bahwa: (1) Teknik Pendampingan dapat meningkatkan motivasi guru menciptakan media pembelajaran di TK Tunas Harapan (2) Teknik Pendampingan dapat meningkatkan motivasi guru menciptakan media pembelajaran dalam melaksanakan tugas intrakurikuler dan ekstrakurikuler.

\section{DAFTAR PUSTAKA}

Badu A.M Abram. 2012. Disertasi Pengembangan Model Pelatihan Pendampingan dalam rangka peningkatan kompetensi pendamping (Studi pada Kelompok Usaha Konveksi Di Kota Gorontalo). Bandung: UPI

Balai Pengembangan Pendidikan Pendidikan Luar Sekolah dan Pemuda. 2007. Materi Diklat Tenaga Pendidik PAUD Tentang Gerak Dan Lagu. Depdiknas

Coni Semiawan. 1999. Perkembangan Belajar Peserta Didik. Depdikbud Dikti. Proyek pendidikan guru sekolah dasar.

Djamarah Bahri Syaiful Drs dan Zain Aswan Drs. 2010. Strategi Belajar Mengajar. Rineka Cipta: Jakarta

Kurniasih. Dan Sani.2014. Sukses Mengimplementasikan Kurikulum 2013. Kata Pena: Jakarta

Kosasih. 2014. Strategi Belajar dan pembelajaran Implementasi Kurikulum 2013. Yrama Widya:Bandung

Rusman. 2012. Model-Model Pembelajaran. Mengembangkan Profesionalisme Guru. Edisi II. PT. Raja Grafindo Persada: Jakarta

Rusman. 2012. Model-Model Pembelajaran. Mengembangkan Profesionalisme Guru. Edisi II. PT. Raja Grafindo Persada: Jakarta

Slameto, Drs. 2010. Belajar dan Faktor-Faktor Yang Mempengaruhinya. Rineka Cipta: Jakarta

Seefeldt Carol dan Wasik A. Barbara. 2008. Pendidikan Anak Usia Dini. Jakarta: PT Inclek

Uno B Hamzah, M.Pd Dr. 2011. Teori Motivasi dan Pengukurannya Analisis Di Bidang Pendidikan. PT Bumi Aksara: Jakarta.

Yani Ahmad. 2014. Mindset Kurikulum 2013. Alfabeta: Bandung 